\title{
Effect of Cymbopogon Citratus on Oxidative Stress Markers in Erythrocytes from Postmenopausal Woman: A Pilot Study
}

\author{
Gabriela Tassotti Gelatti ${ }^{1,2}$, Roberta Cattaneo Horn ${ }^{1}$, Natacha Cossettin Mori ${ }^{1}$, Evelise Moraes Berlezi ${ }^{2}$, Ana \\ Caroline Tissiani ${ }^{1}$, Mariana Spanamberg Mayer ${ }^{1} \&$ Daiana Meggiolaro Gewehr ${ }^{2}$ \\ ${ }^{1}$ Center of Health Sciences and Agrarian, Laboratory Medicinal Plants and Oxidative Stress, LAMOX, Cruz \\ Alta University, UNICRUZ, Cruz Alta, Rio Grande do Sul, Brazil \\ ${ }^{2}$ Department of Life Sciences, Laboratory of Clinical Analysis, UNILAB, Regional University of Northwestern \\ Rio Grande do Sul, UNIJUI, Ijuí, Rio Grande do Sul, Brazil \\ Correspondence: Natacha Cossettin Mori, Cruz Alta University (UNICRUZ), Cruz Alta, Rio Grande do Sul, \\ Brazil. E-mail: natachamori@msn.com
}

Received: November 5, 2015 Accepted: December 7, 2015 Online Published: December 21, 2015

doi:10.5539/jps.v5n1p20

URL: http://dx.doi.org/10.5539/jps.v5n1p20

\begin{abstract}
Objective: Analyzing "in vitro" the antioxidant activity of the lemon grass (Cymbopogon citratus Stapf) over markers of oxidative stress in erythrocytes of women on postmenopausal period. Method: Total blood with anticoagulant has been collected from 28 women on postmenopausal. The plasma was discarded. The diluted erythrocyte on $5 \%$ with saline and divided in 5 groups of treatment: Group 0 : erythrocytes without treatment; Group 5,10,25 and 50 erythrocytes treated respectively with 5, 10,25 and $50 \mathrm{~g} / \mathrm{L}$ of infusion of lemon grass, in water bath on $37^{\circ} \mathrm{C}$ for 1 hour. After this period the erythrocytes were hemolysated in vortex and on the supernatant were evaluated the level of the Thiobarbituric Acid Reactive Substances (TBARS), Carbonylated Proteins (PCs) and of the Reduced Glutathione (GSH). Results: There were no significant alterations on the PCs levels of the studied groups. However the TBARS levels got reduced on the group 25 and the GSH levels got increased on the group 50. Conclusion: These results indicate that the lemon grass seems to be an effective antioxidant agent when it's used in infusions with concentration of 25 and $50 \mathrm{~g} / \mathrm{L}$.
\end{abstract}

Keywords: antioxidant effect, Cymbopogom citratus, postmenopausal

\section{Introduction}

The postmenopausal period is of major importance to women's lives as it involves substantial effects on social and clinical aspects, adversely affecting the quality of life of the same. In this context, changes stand out from the normal aging process and also consequences of endogenous estrogen decline, such as the signs and symptoms observed in this period (Neves, 2002; Bezerra et al., 2015). The women related to Araújo et al. (2015) the symptoms most commons in this phase where stood out the nervousness, hot flashes and paresthesy. It should be noted that the occurrence of oxidative stress might present as an aggravating factor, considering that increases the predisposition to numerous diseases. The occurrence of oxidative stress in postmenopausal phase may be related to changes in lipid profile with consequent lipid peroxidation caused by reduced estrogen (Keaney et al., 2003; Kolesnikova et al., 2015). The oxidative stress occurs when the balance between production and elimination of reactive oxygen species (ROS) what may trigger specific factors responsible for oxidative damage in the cell: over-expression of oncogene genes, generation of mutagen compounds, promotion of heterogenic activity, senile plaque occurrence or inflammation. This leads to cancer, neuron degeneration, cardiovascular diseases, diabetes, kidney diseases (Sosa et al., 2013; Pisoschi \& Pop, 2015).

In this context, the hormone replacement therapy (HRT) is important choice for the treatment of climacteric women, because besides reduced the symptoms related, have act as antioxidants "in vitro" and a positive effect against oxidative stress in brain mitochondria (Ruiz-Larrea et al., 1997; López-Grueso et al., 2014). However, its use is controversial because this treatment also has been associated with thromboembolic events and breast cancer (Borges et al., 2015).

Thus, the natural compounds have been shown to be important therapeutic alternatives, because according to Dornas et al. (2009) the polyphenols present in plants are able of preventing oxidative damage and suppress the 
inflammatory response by inhibiting the action of ROS. Phenolic compounds appear to perform an important role in the absorption and neutralization of ROS (Degáspari \& Waszczynskyj, 2004).

Among the plants recognized for their antioxidant activity, highlight the Cymbopogon citratus Stapf, commonly known as lemon grass. The Cymbopogon citratus (DC) Stapf is a tropical grass with long leaves. The lemon grass is cultivated mainly in tropical and subtropical regions of Asia, South America and Africa (Ákhila, 2010; Boukhatem et al., 2014.). This plant is recognized as one of medicinal plants most used in Latin America for its many therapeutic uses. In traditional medicine is used as an antispasmodic, hypotensive, hepatoprotective, anticonvulsant, analgesic, antiemetic, antitussive, antirheumatic, antiseptic, gastrointestinal disorders and nervous system disorders. However, only some biological properties related to lemongrass were studied in detail (Paranagana et al., 2003; Shah et al., 2011; Koh et al., 2012). Such activity appears to be related to citral, cited as the main essential oil of lemongrass and what appears to be a potent ROS scavenger (Halabi \& Sheikh, 2014). Moreover, Alvis et al. (2012) showed that lemongrass extract has a high content of phenolic compounds and a high agent power reduction and Cheel et al. (2005) identified action of the extract of this plant in the elimination of superoxide radicals and lipid peroxidation in human erythrocytes.

Thus, considering the antioxidant activity attributed to Cymbopogon citratus and the importance of natural compounds as an alternative therapy, the aim of this study was to analyze the action of this plant on oxidative profile on a specific population, in this case, postmenopausal women.

\section{Materials and Methods}

\subsection{Extract Preparation and Infusions}

The Cymbopogon citratus extract was prepared aiming to compare the concentrations of phytochemicals present in it with the concentrations of the infusion. To this was followed by the methodology described Simões et al. (2010), which recommends the use of water and ethanol (70:30) as solvent extractors. The plant material was submitted to manual shake daily for fourteen days, filtered and concentrated in a rotary evaporator. This extract was lyophilized to remove water, thereby obtaining the hydro ethanolic crude extract.

The leaves of Cymbopogon citratus came from the garden of the UNICRUZ, Rio Grande do Sul. The infusion was prepared pouring boiling water on plant leaves and then closed the container for 10 minutes. According the Brazil (2011), this method is suitable for parts of drugs plants less rigid consistency such as leaves, flowers, inflorescences and fruits, or containing volatile active substances.

\subsection{Characterization of the Extract (E) and Infusions (I)}

The determination of total polyphenols was carried according the method Folin-Ciocalteau described by Chandra and Mejia (2004) with modifications. The sample was diluted to concentration of $0.150 \mathrm{mg} / \mathrm{mL}$, added with sodium carbonate solution at $20 \%$ and Folin-Ciocalteau $2 \mathrm{~N}$ reagent. The solution was incubated for 10 minutes and absorbance measurements were realized in triplicate using a spectrophotometer (730 $\mathrm{nm})$. The total polyphenol content was expressed in milligrams of gallic acid equivalents per $\mathrm{ml}$ of the infusion, based on the calibration curve of gallic acid.

The content of total flavonoids was determined according to the method described by Woisky and Salatino (1998). The sample was diluted to one a concentration of $1 \mathrm{mg} / \mathrm{mL}$ and added of aluminum chloride and methanol. The absorbance read at $420 \mathrm{~nm}$. The tests were performed in triplicate and for dosing calculation we used a quercetin standard curve. The flavonoid content was expressed in mg quercetin per $\mathrm{mL}$ of infusion.

The determination of tannins was carried out using the method described by Morrison et al. (1995) with some modifications. The sample was diluted to one a concentration of $25 \mathrm{mg} / \mathrm{mL}$ in methanol. Subsequently was added to the sample, vanillin solution (1 $\mathrm{g}$ vanillin diluted in $100 \mathrm{~mL}$ of methanol) and hydrochloric acid solution concentrated diluted in methanol. The absorbance was read to $500 \mathrm{~nm}$. The analyses were performed in triplicate and the total tannin content will be expressed in milligrams of catechu equivalents per milligrams of infusion, based on the pattern of catechu curve.

\subsection{Ethical Aspects}

This study is linked to the following research projects: "Study the antioxidant effect of different active ingredients" approved by the Research Ethics Committee (CEP) of the Cruz Alta University (UNICRUZ) embodied under opinion number: 15510413.3.0000.5322 and "Female Aging Study" "of the Regional University of Northwest Rio Grande do Sul State (UNIJUÍ) approved by CEP of the UNIJUÍ embodied under opinion number: 864.988 .

The study participants were asked about the feasibility of participation in the research and signed a free and 
informed consent form (ICF).

\subsection{Criterion of Inclusion and Exclusion}

The samples used were from 28 postmenopausal women with at least one year of amenorrhea. Participants who used HRT, antioxidant medicines, vitamin, supplements, or were smokers with chronic diseases were excluded.

\subsection{Experimental Model}

Blood samples of the participants were performed using vacationers containing ethylene diamine tetraacetic acid (EDTA), were excluded hemolysis samples or lipemic samples with insufficient volume to the determinations. Then, the samples were immediately centrifuged at $3000 \mathrm{rpm}$ for 10 minutes and the plasma was removed. The erythrocytes were washed three times with cold saline isotonic solution and centrifuged again. After the final washing erythrocytes were suspended again in saline, then diluted to achieve a $5 \%$ hematocrit according to the technique described by Horn et al. (2015), with minor adaptations. After dilution of erythrocytes a 5\% of each participant were divided into five treatment groups.

- Group 0 (basal): samples without treatment with lemon grass;

- Group 5: samples treated with infusion of $5 \mathrm{~g} / \mathrm{L}$ of lemon grass;

- Group 10: samples treated with infusion of $10 \mathrm{~g} / \mathrm{L}$ of lemon grass;

- Group 25: samples treated with infusion of $25 \mathrm{~g} / \mathrm{L}$ of lemon grass;

- Group 50: samples treated with infusion of $50 \mathrm{~g} / \mathrm{L}$ of lemon grass.

Both groups were incubated for 1 hour in a water bath at $37^{\circ} \mathrm{C}$. After this period the samples were hemolysed by vortex for 30 seconds and centrifuged at $3600 \mathrm{rpm}$ by 15 minutes. The supernatant was stored at $-20^{\circ} \mathrm{C}$ for later realization of analytical determinations.

\subsection{Analytical Determinations}

\subsubsection{Levels of Thiobarbituric Acid Reactive Substances (TBARS)}

Lipid peroxidation was determined according to the formation method of TBARS according Stocks and Dormandy (1991) Protocols. The supernatant $(0.2 \mathrm{~mL})$ was added to the reaction mixture containing trichloroacetic acid $28 \%(\mathrm{v} / \mathrm{v})$; alkaline solution of thiobarbituric acid (TBA) $(0.1 \mathrm{~mol} / \mathrm{L})$ followed by heating at $95^{\circ} \mathrm{C}$. After cooling readings were performed at $532 \mathrm{~nm}$. The results were expressed as nmol MDA $/ \mathrm{g} \mathrm{Hb}$. The total hemoglobin levels were determined from methodology described by the manufacturers of the kit Labtest ${ }^{\circledR}$.

\subsubsection{Levels of Protein Carbonyls (PCs)}

The analyzes were carried out using the technique described by Levine (1990) adapted to erythrocytes, wherein it is used trichloroacetic acid (TCA) to $10 \%(\mathrm{v} / \mathrm{v}), 2 \mathrm{~N}$ hydrochloric acid; 2,4-dinitrophenylhydrazine (DNPH) and $10 \mathrm{mM}$ sodium dodecyl sulfate (SDS), $3 \%(\mathrm{w} / \mathrm{v})$ to the reaction mixture. Readings were taken in visible spectrophotometer at $370 \mathrm{~nm}$. The results were expressed as nmol/carbonyl/mg protein.

\subsubsection{Levels of Reduced Glutathione (GSH)}

They were determined from the technique described by Ellman (1959) adapted to erythrocytes, which uses potassium phosphate buffer (TFK) $1 \mathrm{M}$ at $\mathrm{pH} 7.4$ and 5,5'-dithiobis acid (2-nitrobenzoic acid) (DTNB). The procedure was performed in an ice bath and readings made in a visible spectrophotometer at $412 \mathrm{~nm}$. The results were expressed as $\mu \mathrm{mol} \mathrm{GSH} / \mathrm{mL}$ plasma.

\subsection{Statistical Analysis}

The characterizations of phytochemicals extract and lemon grass infusion were performed in triplicate and the results expressed as mean \pm standard deviation. Data were submitted to student-t test for parametric data considering the significantly different means with a $\mathrm{p}<0.001$.

The analytical determinations of all samples were performed in triplicate and the results thereof were expressed as mean \pm SEM (standard error). The distribution of variables was tested using the Kolmogorov-Smirnov test. Data from all groups studied for the same parameter, were submitted to analysis of variance (ANOVA) of a path followed by the Tukey-Kramer test for parametric data. Significantly different means were considered a $\mathrm{p}<0.05$.

\section{Results and Discussion}

Table 1 describes the total polyphenol levels (E: $24.2 \pm 0.61 \mathrm{mg} / \mathrm{L}$ and I: $4.0 \pm 0.16 \mathrm{mg} / \mathrm{L}$ ), flavonoids (E: 100.7 $\mathrm{mg} \pm 2.30 / \mathrm{L}$ and I: $38.4 \pm 1.23 \mathrm{mg} / \mathrm{L}$ ) and tannins (E: $28.4 \pm 1.01 \mathrm{mg} / \mathrm{L}$ and I: $8.9 \pm 0.38 \mathrm{mg} / \mathrm{L}$ ) present in the extract (E) and infusion (I) of lemongrass in the concentration of $50 \mathrm{~g} / \mathrm{L}$. 
Table 1. Quantification of total polyphenols, tannins and flavonoids in the extract and in the infusion of Cymbopogom citratus. Results were expressed as mean \pm standard deviation

\begin{tabular}{cccc}
\hline \multirow{2}{*}{ Sample } & \multicolumn{3}{c}{ Amounts $(\mathrm{mg} / \mathrm{mL})$} \\
\cline { 2 - 4 } & Total Polyphenols & Flavonoids & Tannins \\
\hline $\begin{array}{c}\text { Extract Cymbopogom } \\
\text { citratus }(\mathrm{E})\end{array}$ & $24.2 \pm 0.61$ & $100.7 \pm 2.30$ & $28.4 \pm 1.01$ \\
\hline $\begin{array}{c}\text { Infusion Cymbopogom } \\
\text { citratus 50g /L (I) }\end{array}$ & $4.0 \pm 0.16^{* * *}$ & $38.4 \pm 1.23^{* * * *}$ & $8.9 \pm 0.38^{* * *}$ \\
\hline *** Indicates significantly different results, considering a $\mathrm{p}<0.0001$
\end{tabular}

These results demonstrate that both the extract as an infusion of the plant have antioxidant activity compounds, however, it appears a significant difference between the concentrations of these components when the two preparations were compared, noting the lowest measurements for the tested infusion. These results corroborate the findings of Cheel et al. (2005), who found the main eliminators ERs both the infusion, and in decoction and Cymbopogom Citratus extract, but with important differences in the relative proportions in each preparation.

Lipids are structural components of the cellular membranes, they participate on the formation of the boundary of permeability of the cells and organelles under cellular on a lipid bi layer way. Besides, they can control the physiological state of organelles changing its biophysical aspects, like polarity and permeability and they can act as signaling molecules (Ayala et al., 2014).

One of the consequences of the oxidative stress is a formation of peroxidation lipid products, which is highly harmful to the organisms because it can alter the permeability, fluidity and membrane integrity, and eventually results in severe cytotoxicity, leading to uncontrolled cell growth or cell death (Umesh \& Ramana, 2013). Signorelli et al. (2006) found that women after menopause have levels of malondialdehyde (MDA) significantly higher when compared to the levels of fertile women, which shows that postmenopausal women have damage to lipids, and also contend that this condition can only be ascribable to the estrogen deficit, which characterizes menopause. Figure 1 shows the levels of lipid peroxidation of erythrocyte in women after menopause, where it is observed that in the group treated with infusion of Cymbopogon citratus to $25 \mathrm{~g} / \mathrm{L}$ there was a lower incidence of lipid peroxidation $(\mathrm{LPO})(\mathrm{p}<0.05)$ when this was compared to the baseline group and the other treatment groups.

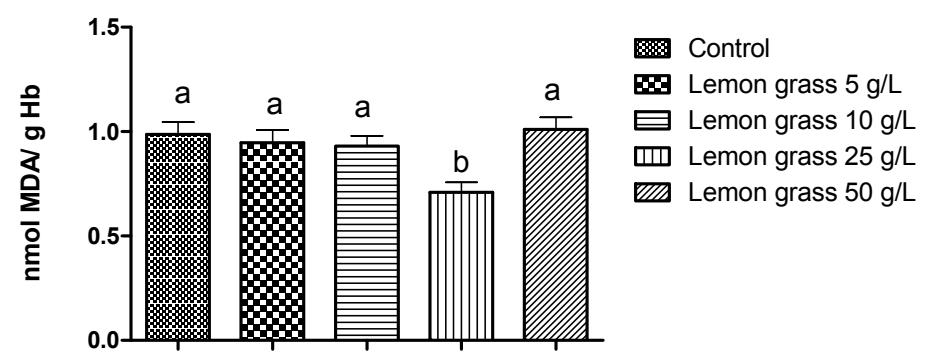

Figure 1. TBARS (nmol MDA/mg Hb) levels in human erythrocytes from postmenopausal women treated "in vitro" with different concentrations of Lemon grass. Different letters represent significantly different statistics, considering a $\mathrm{p}<0.05$

In addition to lipids, proteins are among the main targets of oxidants in the conditions of oxidative stress, because proteins are most abundant in cells (Hohn et al., 2013). These reactions frequently occurs in methionine, cysteine, proline, histidine, arginine, lysine, tryptophan, tyrosine, phenylalanine, and valine residual and as a consequence carbonated composed are generated (Oga et al., 2014).

The carbonylation can be caused by the direct oxidation of the amino-acids rests with EROs, through the formation of reactive intermediates generated during the LPO that can react with the sulfidrile of cysteine group, the group e-amino of lysine or the group imidazole of rests of histidine forming final products advanced from the lipo oxidation or produced by reaction of redactor sugars or from their oxidation products with rests of lysine of proteins, taking to the formation of final products of advanced glycation (Butterfield \& Dalle-Donne, 2012). 
The elevation of the PCs formation can be directly related to the female growing, viewing that with the proximity of the post-menopause a reduction of the estrogen level occurs in women what besides decreasing the fertility of them, it increases the damages in proteins (Voss \& Siems, 2006), viewing that, according to Oge et al. (2003) the estrogen presents antioxidant effect, which is due in part, to its hydro-phenolic structure, which can donate atoms of hydrogen to an instable molecule, becoming a less damageable radical.

The infusions of Cymbopogon citratus in the concentrations tested in this study didn't show effects on the PCs levels when the obtained results were compared among themselves (Figure 2). Showing that although this plant isn't able to decrease the carbonylation of proteins, we can assure that the infusion of Cymbopogon citratus doesn't take to bigger protein damages, thus it doesn't aggravate the conditions of oxidative stress generated by the hormonal decreasing of women in post-menopause period.

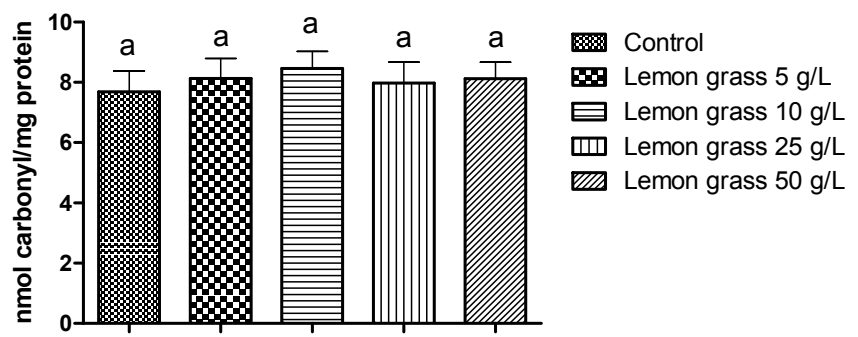

Figure 2. PCS (nmol carbonyl/mg protein) levels in human erythrocytes from postmenopausal women treated "in vitro" with different concentrations of Lemon grass. Different letters represent significantly different statistics, considering a $\mathrm{p}<0.05$

The production of endogenous antioxidants such as GSH, is considered an alternative to combat these oxidative damage caused by ROS, given that it helps neutralize and repair the damage caused by oxidative stress (Ribeiro et al., 2005). Recent data have been showing that the efficiency in this antioxidant system can play an important role in the development of dysfunctions of the female reproductive system (Miquel et al., 2006; Kolesnikova et al., 2012). In this context, the infusion of lemon grass on $50 \mathrm{~g} / \mathrm{L}$ demonstrated an important antioxidant effect, viewing that, in just one hour of treatment in water bath on $37^{\circ} \mathrm{C}$ the plant increased the GSH levels in the concentration of $50 \mathrm{~g} / \mathrm{L}$, what possibly would be favorable to the decreasing of the protein and lipid damages generated in the period of post-menopause in case that the period of contact of the erythrocytes to the infusion were bigger (Figure 3).

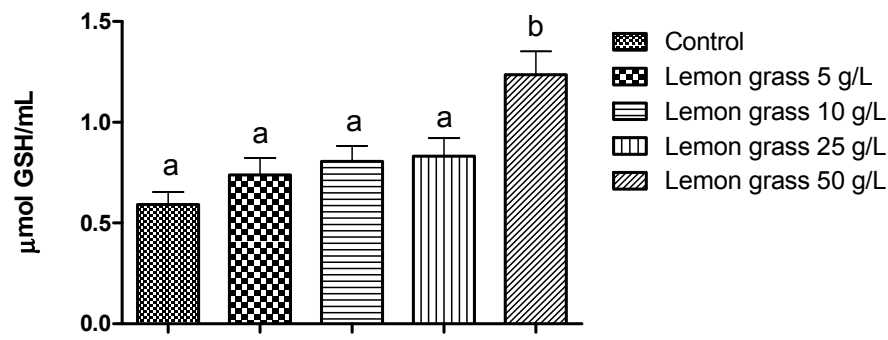

Figure 3. GSH ( $\mu \mathrm{mol} \mathrm{GSH} / \mathrm{mL})$ levels in human erythrocytes from postmenopausal women treated "in vitro" with different concentrations of Lemon grass. Different letters represent significantly different statistics, considering a $\mathrm{p}<0.05$

\section{Conclusion}

The infusions of lemon grass on the concentrations of $25 \mathrm{~g} / \mathrm{L}$ and $50 \mathrm{~g} / \mathrm{L}$ showed that they own a discreet but important antioxidant activity, viewing that they decreased the LPO levels and they increased the GSH levels in some of the tested concentrations. Before that, it becomes fundamental to give continuity on the research about the antioxidant potential of this plant, because besides this one is very used popularly as an infusion, it can be presented as a future therapeutic alternative to the oxidative stress reduction in women on the post-menopause period. 


\section{References}

Alvis, A., Martínez, W., \& Arrazola, G. (2012). Obtención de extractos hidro-alcohólicos de limoncillo (Cymbopogon citratus) como antioxidante natural. Información Tecnológica, 23(2), 3-10. http://dx.doi.org/10.4067/S0718-07642012000200002

Araújo, J. B. S., Santos, G. C., Nascimento, M. A., Dantas, J. G. S., \& Ribeiro, A. S. C. (2015). Avaliação da Intensidade da Sintomatologia do Climatério em Mulheres: inquérito populacional na cidade de Maceió, Alagoas. Caderno de Graduação-Ciências Biológicas e da Saúde-FITS, 2(3), 101-111.

Ákhila, A. (2010). Essential Oil-bearing Grasses: the genus Cymbopogon. New York: CRC Press.

Ayala, A., Muñoz, M. F., \& Argüelles S. (2014). Lipid Peroxidation: production, metabolism, and signaling mechanisms of malondialdehyde and 4-hydroxy-2-nonenal. Oxidative Medicine and Cellular Longevity, 2014. http://dx.doi.org/10.1155/2014/360438

Bezerra, A. G., Pires, G. N., Andersen, M. L., Tufik, S., \& Hachul, H. (2015). Acupuncture to Treat Sleep Disorders in Postmenopausal Women: a systematic review. Evidence Based Complementary and Alternative Medicine, 2015. http://dx.doi.org/10.1155/2015/563236

Borges, T. F. C., Tamazato, A. P. S., \& Ferreira, M. S. C. (2015). Female Sex Hormone Therapy and Thromboembolic Phenomena: Literature Review. Revista Ciências em Saúde, 5(2), 158-168.

Boukhatem, M. N., Ferhat, M. A., \& Kebir, H. T. (2014). Lemon grass (Cymbopogon citratus) essential oil as a potent anti-inflammatory and antifungal drugs. Libyan Journal of Medicine, 19(9), 1-10. http://dx.doi.org/10.3402/ljm.v9.25431

Brazil. (2011). Agência Nacional de Vigilância Sanitária. Formulário de Fitoterápicos da Farmacopéia Brasileira. Brasília.

Butterfield, D. A., \& Dalle-Donne, I. (2012). Redox proteomics. Antioxidants \& Redox Signaling, 17(11), 1487-1489. http://dx.doi.org/10.1089/ars.2012.4742

Chandra, S., \& Meija, E. G. (2004). Polyphenolic compounds, antioxidant capacity and quinone reductase activity of an aqueous extract of Ardisia compressa in comparison to Mate (Ilex paraguaiensis) and Green teas (Camellia sinensis). Journal of Agricultural and Food Chemistry, 52, 3583-3589. http://dx.doi.org/10.1021/jf0352632

Cheel, J., Theodoluz, C., Rodrigues, J., \& Schmeda-Hirschmann, G. (2005). Free radical scavengers and antioxidants from Lemongrass (Cymbopogon citratus (DC.) Stapf.). Journal of Agricultural and Food Chemistry, 53(7), 2511-2517. http://dx.doi.org/10.1021/jf0479766

Degáspari, C. H., \& Waszczynskyj, N. (2004). Propriedades antioxidantes de compostos fenólicos. Visão acadêmica, 5(1), 33-40.

Dornas, W. C., Oliveira, T. T., Rodrigues-das-Dores, R. G., Santos, A. F., \& Nagem, T. J. (2009). Flavonóides: potencial terapêutico no estresse oxidativo. Revista de Ciências Farmacêuticas Básica e Aplicada, 28(3), 241-249.

Ellman, G. L. (1959). Tissue sulfhydryl group. Archives of Biochemistry and Biophysics, 82(1), 70-77. http://dx.doi.org/10.1016/0003-9861(59)90090-6

Halabi, M. F., \& Sheikh, B. Y. (2014). Antiproliferative effect and phytochemical analysis of Cymbopogon citratus extract. BioMed Research International. http://dx.doi.org/10.1155/2014/906239.

Hohn, A., Konig, J., \& Grune, T. (2013). Protein oxidation in aging and the removal of oxidized proteins. Journal of Proteomics, 30(92), 132-159. http://dx.doi.org/10.1016/j.jprot.2013.01.004

Horn, R. C., Soares, J. C., Mori, N. C., Gelatti, G. T., Manfio, C. E., Golle, D. P., Koefender, J., Deuschle, R., \& Oliveira, C. (2015). Antioxidant effect of Physalis peruviana fruit aqueous extract. Journal of Agricultural Science, 7(12), 137-143.

Keaney, J. F., Larson, M. G., Vasan R. S., Wilson, P. W., Lipinska, I., Corey, D., \& Massaro, J. M. (2003). Obesity and systemic oxidative stress clinical correlates of oxidative stress in the Framingham Study.

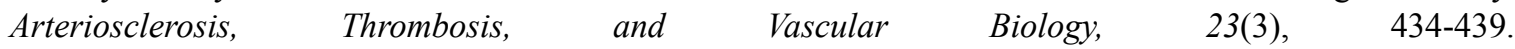
http://dx.doi.org/10.1161/01.ATV.0000058402.34138.11

Koh, P. H., Mokhtar, R. A., \& Iqbal, M. (2012). Antioxidant Potential of Cymbopogon Citratus Extract: alleviation of carbon tetrachloride induced hepatic oxidative stress and toxicity. Human \& Experimental 
Toxicology, 31(1), 81-91. http://dx.doi.org/10.1177/0960327111407226

Kolesnikova, L. I., Darenskaya, M. A., Grebenkina, L. A., Labygina, A. V., Suturina, L.V., Dolgikh, M. I., \& Shiphineeva, T. I. (2012). Activity of lipid peroxidation in infertile women from different populations. Bulletin of Experimental Biology and Medicine, 154(2), 203-205.

Kolesnikova, L., Semenova, N., Madaeva, I., Suturina, L., Solodova, E., Grebenkina, L., \& Darenskaya, M. (2015). Antioxidant status in peri and postmenopausal women. Maturitas, 81(1), 83-87. http://dx.doi.org/10.1016/j.maturitas.2015.02.264

Levine, R. L. (1990). Determination of carbonil in oxidatively modified proteins. Methods in Enzymology, 186, 464-468. http://dx.doi.org/10.1016/0076-6879(90)86141-H

López-Grueso, R., Gambini, J., Abdelaziz, K. M., Monleón, D., Díaz, A., Alami, M. E., \& Bonet-Costa, V. (2014). Early, but not late onset estrogen replacement therapy prevents oxidative stress and metabolic alterations caused by ovariectomy. Antioxidants \& Redox Signaling, 20(2), 236-246. http://dx.doi.org/10.1089/ars.2012.5112

Miquel, J., Ramirez-Bosca, A., Ramirez-Bosca, J. V., \& Alperi, D. (2006). Menopause: a review on the role of oxygen stress and favorable effects of dietary antioxidants. Archives of Gerontology and Geriatrics, 42(3), 289-306. http://dx.doi.org/10.1016/j.archger.2005.08.005

Morrison, M., Asiedu, E. A., Stuchbury, T., \& Powell, A. A. (1995). Determination of lignin and tannin contents of cowpea seeds coats. Annals of Botany, 76, 287-90. http://dx.doi.org/10.1006/anbo.1995.1097

Neves, C. M. (2002). Is there a menopausal medicine? The past the present and the future. Maturitas, 43(1), 79-84. http://dx.doi.org/10.1016/S0378-5122(02)00151-2.

Oga, S., Camargo, M. M. A., \& Batistuzzo, J. A. (2014). Fundamentos de Toxicologia. 4.ed. São Paulo. Atheneu Editora.

Oge, A., Sezer E. D., Ozgönül, M., Bayraktar, F., \& Sözmen, E. Y. (2003). The effects of estrogen and raloxifene treatment on the antioxidant enzymes and nitrite-nitrate levels in brain cortex of ovariectomized rats. Neuroscience Letters, 338(3), 217-220. http://dx.doi.org/10.1016/S0304-3940(02)01416-7

Paranagana, P. A., Abeysekera, K. H., Abeywickrama, K., \& Nugaliyadde, L. (2003). Fungicidal and anti-aflatoxigenic effects of the essential oil of Cymbopogon citratus (DC.) Stapf. (lemongrass) against Aspergillus flavus isolated from stored rice. Letters in Applied Microbiology, 37(1), 86-90. http://dx.doi.org/10.1046/j.1472-765X.2003.01351.x

Pisoschi, A. M., \& Pop, A. (2015). The Role of Antioxidants in the Chemistry of Oxidative Stress: a review. European Journal of Medicinal Chemistry, 97, 55-74. http://dx.doi.org/10.1016/j.ejmech.2015.04.040

Ribeiro, S. M. R., Queiroz, J. H., Peluzio, M. C. G., Costa, N. M. B., Matta, S.L. P., \& Queiroz, M. E. L.R. (2005). A formação e os efeitos de espécies reativas de oxigênio no meio biológico. Bioscience Journal, 21(3), 133-149.

Ruiz-Larrea, M. B., Leal, A. M., Martin, C., Martinez, R., \& Lacort, M. (1997). Antioxidant action of estrogens in rat hepatocytes. Revista Española de Fisiologia, 53(2), 225-229.

Shah, G., Shri, R., Panchal, V., Sharma, N., Singh, B., \& Mann, A. S. (2011). Scientific basis for the therapeutic use of Cymbopogon citratus stapf (Lemon grass). Journal of Advanced Pharmaceutical Technology \& Research, 2(1), 3- 8. http://dx.doi.org/10.4103/2231-4040.79796.

Signorelli, S. S., Neri S., Sciacchitano, S., Pino, L. D., Costa, M. P., Marchese, G., \& Celotta, G. (2006). Behaviour of some indicators of oxidative stress in postmenopausal and fertile women. Maturitas, 10(53), 77-82. http://dx.doi.org/10.1016/j.maturitas.2005.03.001

Simões, C. M. O., Shenkel, E. P., Mello, J. C. P., Mentz, L. A., \& Petrovick, P. R. (2010) Farmacognosia: da planta ao medicamento. Florianópolis. UFGRS/UFSC.

Sosa, V., Moliné, T., Somoza R., Paciucci, R., Kondoh, H., \& Leonart, M. E. (2013). Oxidative Stress and Cancer: an overview. Ageing Research Reviews, 12(1), 376-390. http://dx.doi.org/10.1016/j.arr.2012.10.004

Stocks, J., \& Dormandy, T. L. (1971). The autoxidation of human red cell lipids induced by hydrogen peroxide. British Journal of Haematology, 20(1), 95-111. http://dx.doi.org/10.1111/j.1365-2141.1971.tb00790.x

Umesh, C. S. Y., \& Ramana, K. V. (2013). Regulation of NF- $\kappa$ B-induced inflammatory signaling by lipid peroxidation-derived aldehydes. Oxidative Medicine and Cellular Longevity, 2013, 1-11. 
http://dx.doi.org/10.1155/2013/690545

Voss, P., \& Siems, W. (2006). Clinical oxidation parameters of aging. Free Radical Research, 40(12), 1339-1349. http://dx.doi.org/10.1080/10715760600953859

Woisky R. G., \& Salatino, A. (1998). Analysis of própolis: some parameters and procedures for chemical quality $\begin{array}{lllll}\text { control. Journal of Apicultural } & \text { Research, }\end{array}$ http://dx.doi.org/10.1080/00218839.1998.11100961

\section{Copyrights}

Copyright for this article is retained by the author(s), with first publication rights granted to the journal.

This is an open-access article distributed under the terms and conditions of the Creative Commons Attribution license (http://creativecommons.org/licenses/by/3.0/). 